Diabetologia 6, 292-299 (1970)

\title{
Differences in the Development of the Obese-hyperglycemic Syndrome in obob and NZO Mice*
}

\author{
L. Herberg, E. Major, U. Hennigs, D. GrünekLee, G. Freytag and F.A. Gries
}

Diabetes-Forschungsinstitut und 2. Medizinische Klinik, Universität Düsseldorf, Pathologisches Institut, Universität Hamburg, Physiologisch-Chemisches Institut, Universität Göttingen, Germany

Summary. Marked differences were shown in the development of the obese-hyperglycemic syndrome in NZO and $a b a b$ mice. - In NZO mice glucose tolerance decreases continuously with increasing age and body weight. - In obob mice three phases in the development of the obese-hyperglycemic syndrome are differentiat $\epsilon$ d. In the first, dynamic phase glucose tolerance decrea ses and insulin secretion increases as does body weight. The intermediary or transitional phase, when the animals weigh about $\mathbf{5 5} \mathrm{g}$, is characterised by rapidly changing glucose patterns, i. e. an extremely poor glucose tolerance and extremely high serum insulin level is followed by improving glucose tolerance and decreasing insulin levels. In the third, static phase blood sugar values and serum insulin levels have nearly returned to those of the lean littermates. Body weight slowly decreases. The changes in glucose tolerance and serum insulin are parallelled by changes in islet cell morphology. The gluconeogenic ca. pacity is increased during the dynamic and transitional phases, it declines during the static phase.

Différences dans le développement de l'obésité et de l'hyperglycémie chez les souris obob et $\mathrm{NZO}$

Résumé. En étudiant le développement du syndrome obésité-hyperglycémie des souris obob et $\mathrm{NZO}$, des différences prononcées ont été trouvées entre ces deux souches. - Chez la souris NZO, la tolérance an glucose décroît progressivement avec l'augmentation du poids et de l'âge. - Chez la souris obob, on distingue un développement du syndrome en 3 phases. Dans un premier temps dynamique, la tolérance au glucose diminue alors que la sécrétion d'insuline et le poids corporel augmentent. La phase intermédiaire ou transitoire - lorsque les animaux pèsent environ $55 \mathrm{~g}$ - est caractérisée par un changement rapide de l'allure des courbes de tolérance, c'est à dire qu'une mauvaise tolérance au glucose avec insulinémie élevée est suivie d'une amélioration de la tolérance au glucose et d'une diminution de l'insulinémie. Dans un troisième temps, statique, les taux de glucose sanguin et d'insuline circulante sont voisins de ceux des souris normales de même âge. Le poids corporel diminue lentement. Les modifications de la tolérance au glucose et l'insulinémie vont de pair avec des modifications morphologiques des cellules des îlots pancréatiques. La gluconéo. génèse est accrue dans les phases dynamique et transitoire, mais diminuée dans la phase statique.

Unterschiedliche Entwicklung des Fettsucht-Hyperglykämie-Syndroms bei obob und NZO-Mäusen

Zusammenfassung. Ein Vergleich der altersbedingten Veränderungen der Glucosetoleranz bei $a b o b$ - und $N Z O$ Mäusen ergab folgende Unterschiedo: Die Glucosetoleranz der NZO-Mäuse nimmt mit zunehmendem Alter und Körpergewicht progressiv ab. Bei obob-Mäusen lassen sich eine dynamische (I), eine intermediëre (II) und eine sta. tische (III) Phase unterscheiden. Im Verlauf der Phase I nimmt die Glucosetoleranz ab, die Seruminsulinkonzentrationen und das Körpergewicht nehmen zu. Zu Beginn der Phase II (Körpergewicht ca. $55 \mathrm{~g}$ ) ist die Glucosetoleranz sshr schlecht, die Seruminsulinkonzentrationen liegen sehr hoch; später verbessert sich die Glucosetoleranz etwas und die Insulinkonzentrationen sinken ab. Während der Phase III kehren Blutzucker und Seruminsulinkonzentrationen beinahe in den Bereich der bei Normaltieren des gleichen Wurfes gemessenen. Werte zurück. Das Körpergewicht zeigt eine langsame Reduktion. Die Langerhans'schen Inseln zeigen während der Phasen I und II eine deutliche Hvperplasie, die sich im Verlaufe der Phase III weitgehend zurückbildet. Während der Phasen. I und II sind die Aktivitäten gluconeogenetischer Enzyme deutlich erhöht.

Key-words: Spontaneous diabetes, mutation obob, $N Z O$ mice, diabetes in mice, obesity in mice, hereditary obesity, insulin, Beta-cells of pancreatic islets, adipose tissue.
American obese hyperglycemic mice (obob mice) and New Zealand obese mice (NZO mice) have been referred to as possible models for maturity-onset human diabetes. Both strains are characterised by hyperglycemia coexisting with hyperinsulinemia. However, previous investigations indicate that the syndrome in these two strains of mice cannot be regarded as identical. In $o b o b$ mice the blood sugar during glucose load increases with increasing body weight and age of the animals [25]. In NZO mice, however, no correlation between glucose tolerance and body weight was reported [5]. Both strains of mice show hyperinsulinemia and increased pancreatic insulin content. However,

* Supported by grants from the Deutsche Forschungs. gemeinschaft, Bad Godesberg, and Landesamt für Forschung des Landes Nordrhein-Westfalen, Germany. the amount of insulin in the pancreas of $o b o b$ mice [16] is about 6 times greater than in the pancreas of NZO mice [21]. Because of the differences in the development of obesity and hyperglycemia as well as hyperinsulinemia and pancreatic insulin content we studied carbohydrate metabolism in vivo, both in NZO and $o b o b$ mice. In addition, the gluconeogenic capacity of the liver in vitro and the histology of pancreatic B-cells were investigated in $a b o b$ mice.

\section{Materials and Methods}

The following animals were used: American obese hyperglycemic mice ( $o b o b$ mice) and their lean littermates were obtained from The Jackson Memorial Laboratories, Bar Harbor, Maine, USA. 
New Zealand obese mice (NZO) which originated from the strain described by Bielschowsky and Bielschowsky [1] were from our inbred colony. They were weaned at 21 days of age and separated according to their sex between 30 and 35 days of age. $0 b o b$ mice were obtained at the age of $5-6$ weeks.

For all studies only male obob and male NZO mice were used. The animals were housed in a room with a regulated temerature $\left(25 \pm 22^{\circ} \mathrm{C}, 65 \%\right.$ relative humidity $)$ and artificial light ( 8 a.m. to 8 p.m.). 5 animals were kept together in any one plastic cage (floor area $23 \times 17$ $\mathrm{cm}$ ) covered with saw dust. The animals were allowed free access to food and tap water. The food was in pellet form and produced by Intermast GmbH, Bockum-Hoevel, Germany. Food was composed as follows:

Composition:

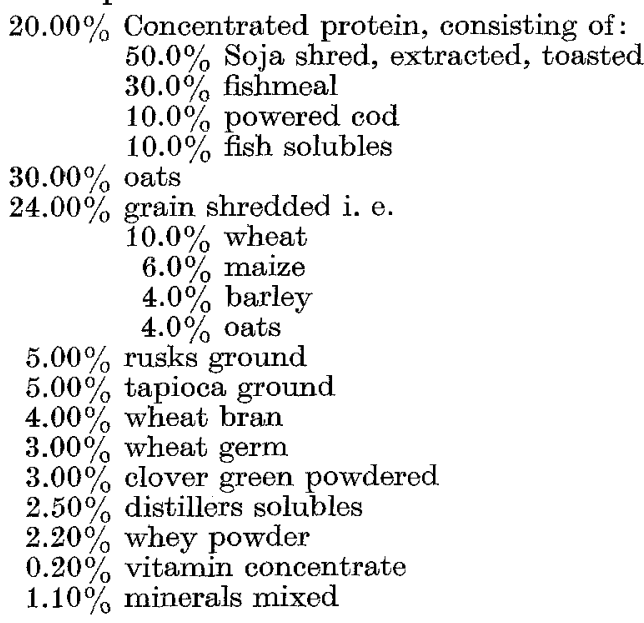

$100.00 \%$

Weender Analysis :

$\begin{array}{lr}\text { crude protein } & 20.20 \% \\ \text { crude fat } & 4.74 \% \\ \text { crude fibre } & 3.50 \\ \text { ash } & 6.56 \% \\ \mathrm{H}_{2} \mathrm{O} & 11.20 \% \\ \mathrm{~N} \text {-free extracts } & 53.80 \%\end{array}$

Analytical carbohydrate content:

free carbohydrate $30.10 \% \pm 5 \%$

Addition of vitamin

(per $\mathbf{k g}$ diet are added)

Vitamin A 30000 T.E. Ca-D-panthothenat $21 \mathrm{mg}$

$\begin{array}{lcclcc}\mathrm{D}_{3} & 6000 & \mathrm{I} . \mathrm{F} & \text { Nicotinamide acid } & 60 & \mathrm{mg} \\ \mathrm{F}_{1} & 30 & \mathrm{mg} & \text { Folic acid } & 2.2 \mathrm{mg} \\ \mathrm{K}_{3} & 2.2 \mathrm{mg} & \text { Biotin } & 100 & \mathrm{mg} \\ \mathrm{B}_{1} & 9 & \mathrm{mg} & \text { Cholinchloride } & 300 & \mathrm{mg}\end{array}$

$\begin{array}{lll}\mathrm{B}_{2} & 9 & \mathrm{mg} \\ \mathrm{B}_{6} & 9 & \mathrm{mg}\end{array}$

$\begin{array}{lll}\mathrm{B}_{12} & 30 & \mathrm{mg}\end{array}$

Mineral content

(per $\mathrm{kg}$ diet are contained)

Calcium

Phosphorus

Magnesium

Potassium

Sodium

(of this $\mathrm{NaCl}$ )
Sulphur
Ferrum
Manganese
Zine
Copper
Cobalt
Iodine

$750 \mathrm{mg}$

$110 \mathrm{mg}$

$230 \mathrm{mg}$

$55 \mathrm{mg}$

$35 \mathrm{mg}$

$11 \mathrm{mg}$

$800 \mathrm{mg}$

$450 \mathrm{mg}$

Amino-acid content

(per $\mathrm{kg}$ diet are contained)

$\begin{array}{lr}\text { Glycerine } & 12600 \mathrm{mg} \\ \text { Alanine } & 12400 \mathrm{mg} \\ \text { Cystine } & 2300 \mathrm{mg} \\ \text { Serine } & 8900 \mathrm{mg} \\ \text { Methionine } & 3500 \mathrm{mg} \\ \text { Threonine } & 8900 \mathrm{mg} \\ \text { Valine } & 13200 \mathrm{mg} \\ \text { Leucine } & 17600 \mathrm{mg} \\ \text { Isoleucine } & 9000 \mathrm{mg} \\ \text { Asparaginic acid } & 21600 \mathrm{mg} \\ \text { Glutaninic acid } & 35700 \mathrm{mg} \\ \text { Arginine } & 16300 \mathrm{mg} \\ \text { Lysine } & 15200 \mathrm{mg} \\ \text { Phenylalanine } & 9900 \mathrm{mg} \\ \text { Tyrosine } & 8100 \mathrm{mg} \\ \text { Tryptophane } & 12800 \mathrm{mg} \\ \text { Histidine } & 7200 \mathrm{mg} \\ \text { Proline } & 13200 \mathrm{mg}\end{array}$

Deviations in the composition of aminoacid patterns are $\pm 5-20 \%$ according to raw materials.

Blood samples were obtained from the tip of the tail. For glucose determination, blood was collected in plastic centrifuge tubes without anticoagulant. Blood glucose was measured by the o-toluidine-method [12]. For serum insulin determination, blood samples of $2-3$ mice were pooled, left for $2 \mathrm{~h}$ at room temperature, centrifuged and the serum stored at $-18^{\circ} \mathrm{C}$ until assayed Serum insulin was measured according to Hales and Randle, method C [7]. Reagents were supplied by the Radiochemical Centre, Amersham, England. Crystalline bovine insulin (27 IU/mg, Farbwerke Hoechst, Germany) was used as a standard. On each sample, triplicate assays were carried out. Glucose tolerance tests were started at 8 a.m. and performed on nonfasted mice in the room with regulated temperature. $2.5 \mathrm{~g}$ glucose $/ \mathrm{kg}$ body weight were given intraperitoneally as a $10 \%$ glucose solution. Blood specimens were taken at various intervals between 0 and 180 minutes after glucose load. ${ }^{14} \mathrm{CO}_{2}$-fixation was studied in liver slices according to L'age et al. (14). $\mathrm{Na}_{2}{ }^{14} \mathrm{CO}_{3}$ was supplied by The Radiochemical Centre, Amersham, England. Pyruvate carboxylase was assayed as described by Henning and Seubert [10]. Phosphoenolpyruvate carboxykinase was assayed according to Seubert and Huth [20]. Protein was determined as described by Lowry and coworkers [15]. For histological examination slices of pancreas were stained according to Schiebler and Schiessler [18] and investigated under UV- or visible light.

\section{Results and Discussion}

Body weight. In agreement with earlier observations by Crofford and Davis [5] we noted that during 
the first months of age NZO mice gain body weight rapidly (Fig. 1a). Thereafter, weight increases more slowly but continuously by about $1.5 \mathrm{~g}$ per month. The highest body weight of approximately $70 \mathrm{~g}$ is reached at the end of the observation period when the animals are 12 months old.

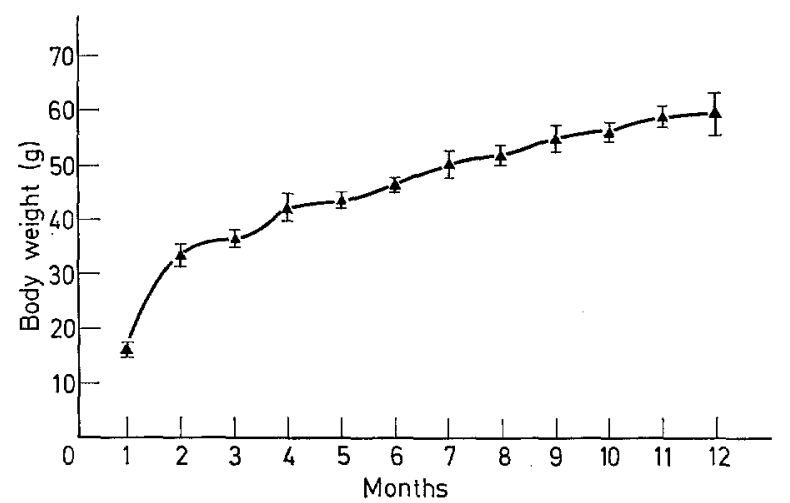

weight, and a rapid decrease may be seen shortly before spontaneous death occurs.

Similar weight curves were observed by Westman [25]. The slightly different age-weight-relationship and maximal weight patterns may be a peculiarity of the Swedish colony of $o b o b$ mice.

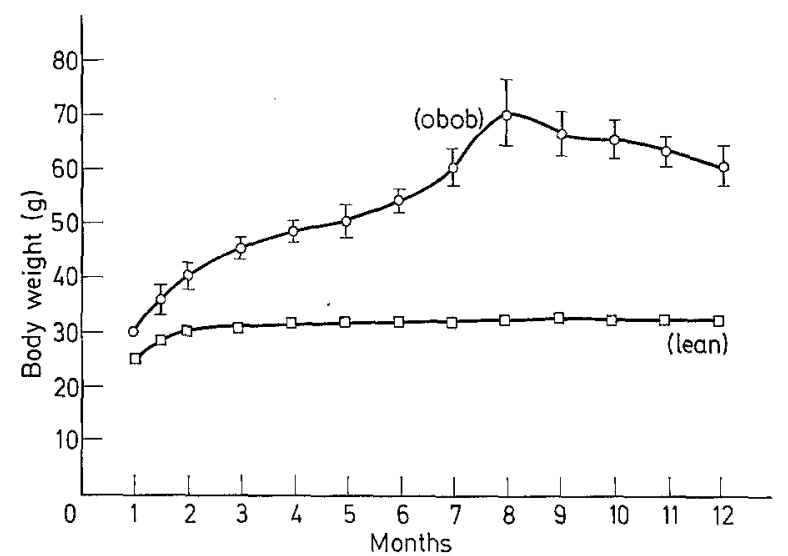

Fig. 1 a. Body weight of New Zealand obese mice $(\delta)$ of different ages. b. Body weights of American obese hyperglycemic mice $(o b o b)$ and lean mice of different ages $(\delta)$. Mean \pm SEM based on observations on between 20 and 50 animals

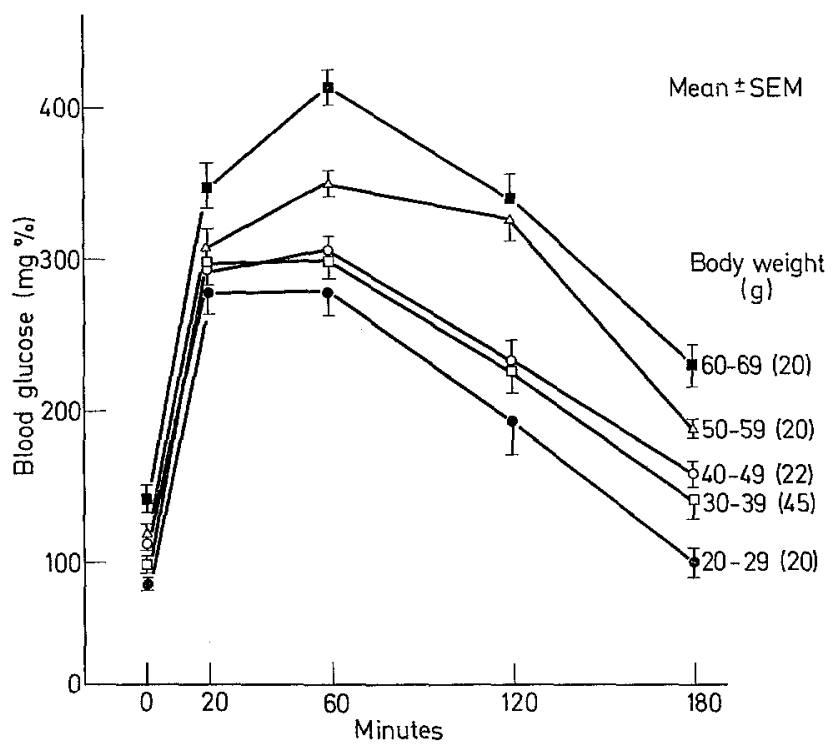

Fig. 2. Glucose tolerance test $(2.5 \mathrm{~g} / \mathrm{kg}$ body weight i.p.) in New Zealand obese mice with contribution to body weight. The number of animals is indicated in parentheses

While the lean littermates of $a b o b$ mice do not change their average body weight of about $30 \mathrm{~g}$ after the second month of age, different periods in the development of obesity may clearly be distinguished in $o b o b$ mice (Fig. 1 b). A rapid gain in weight during the first three months of age is followed by a period of about 3-4 months in which weight increment is slower. Thereafter, the animals increase their weight again rapidly until the maximum is reached at about 10 months of age. Later there is a slight reduction in body

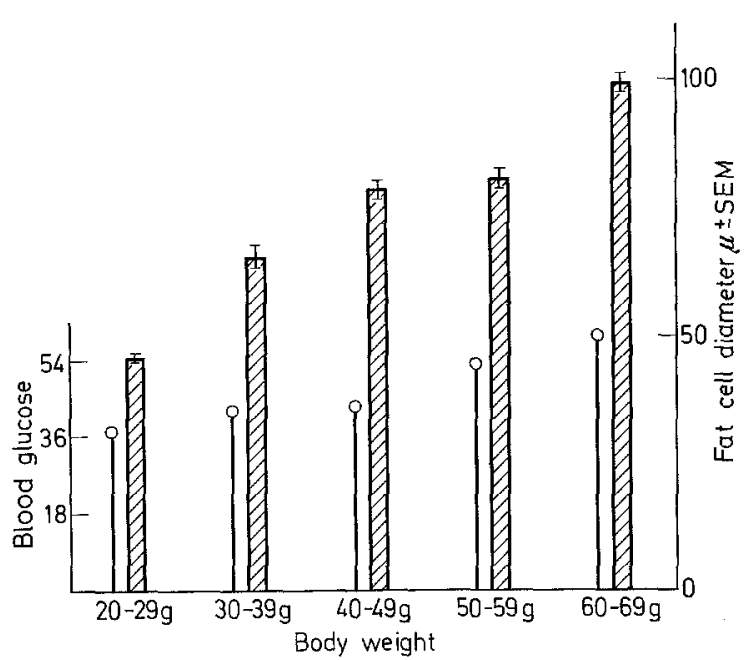

Fig. 3. Blood glucose and fat cell diameter with contribution to body weight in New Zealand obese mice. 0 = average blood glucose $\left(\mathrm{mg}^{2} \% \times 10^{3}\right)$ after glucose load between 0 and $180 \mathrm{~min}$. Animals studied: blood glucose $20-45$, fat cell diameter $10-18$

Blood sugar levels during glucose tolerance test in NZO mice. In NZO mice (Fig. 2) non-fasting blood sugar values slightly increase with growing body weight. In contrast to Crofford and Davis [5] we observed significant weight-dependent differences in blood sugar levels after glucose load, which were most remarkable in animals weighing more than $50 \mathrm{~g}$. The slope after $60 \mathrm{~min}$ post glucose load is comparable in all groups studied, except in the group weighing $50-59 \mathrm{~g}$ which exhibits a more biphasic decline. At 
the end of the test period the blood sugar in the group of animals weighing $20-29 \mathrm{~g}$ has returned to baseline, whereas in the other weight groups, the blood sugar values are significantly greater than at the beginning of the test. In this strain of mice there was not only a

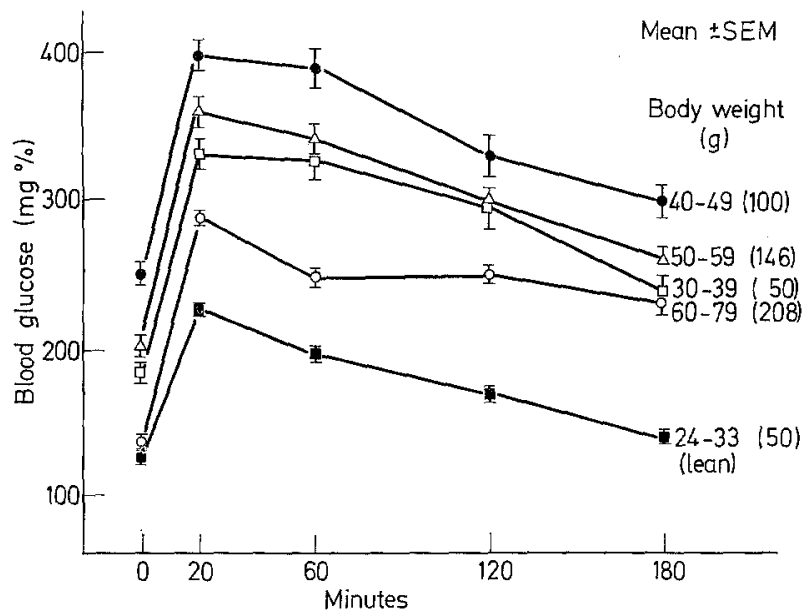

Fig. 4. Glucose tolerance test (2.5 $\mathrm{g} / \mathrm{kg}$ body weight i.p.) in American obese-hyperglycemic mice (obob) with contribution to body weight

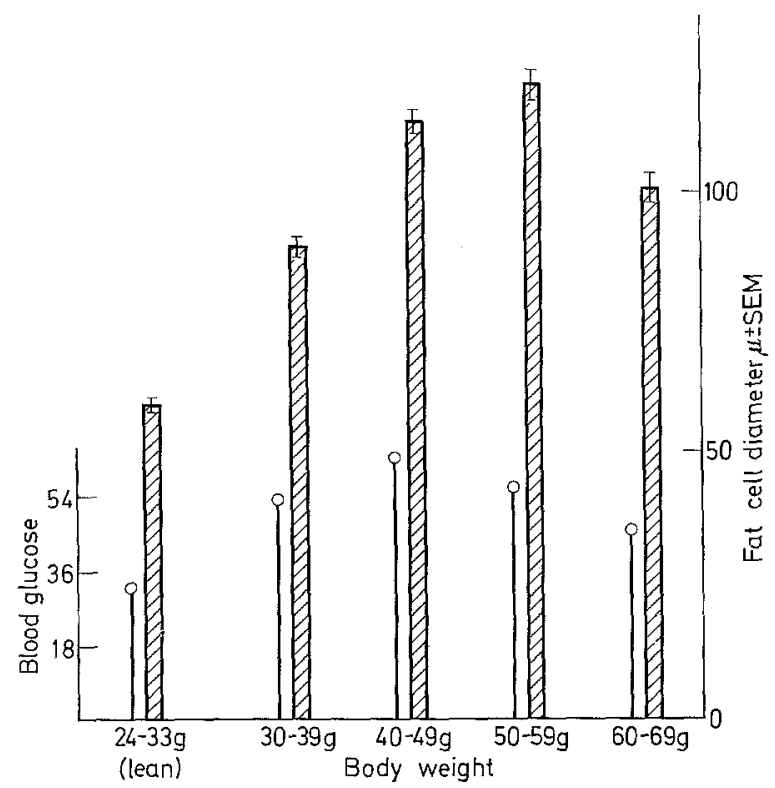

Fig. 5. Blood glucose and fat cell diameter with contribution to body weight in American obese-hyperglycemic mice $(o b o b) .0=$ average blood glucose $\left(\mathrm{mg} \% \times 10^{3}\right)$ after glucose load between 0 and $180 \mathrm{~min}$. Animals studied blood glucose $50-208$, fat cell diameter $7-52$

strong correlation between body weight and glucose tolerance but, as shown in Fig. 3, also between the average blood glucose levels after a glucose load between 0 and $180 \mathrm{~min}$ and the fat cell diameters. The same relationship was previously described in human obesity by Salans [17].
Blood sugar and insulin levels during glucose tolerance tests in $o b o b$ mice. In $a b o b$ mice (Fig. 4) there is an increase in non-fasting blood. sugar values only in the initial phase which parallels increasing body weight.

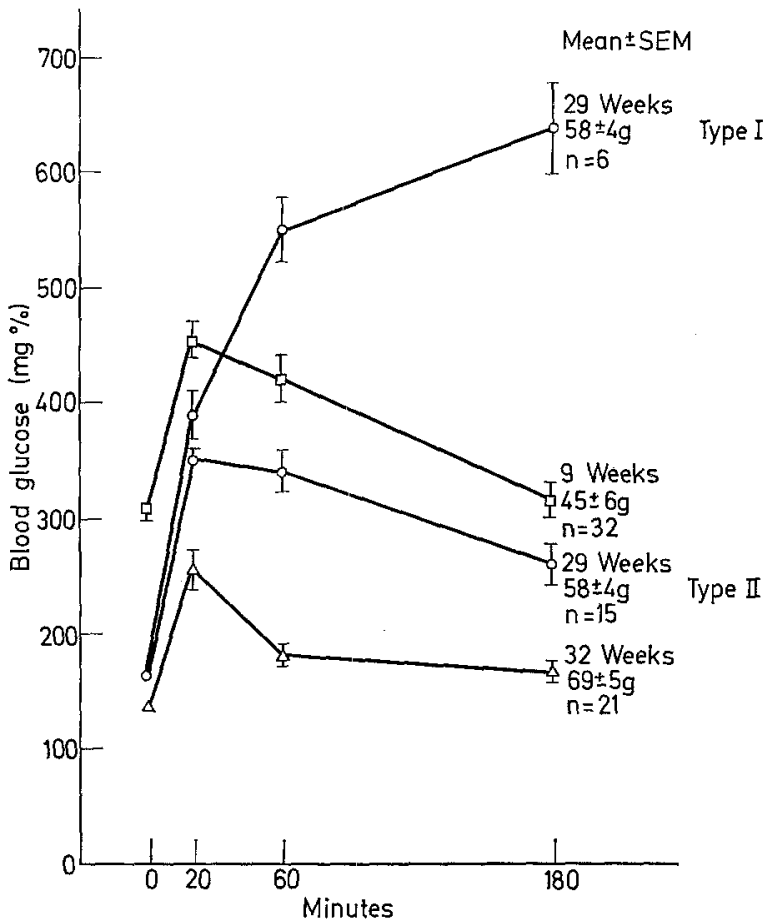

Fig. 6. Glucose tolerance test $(2.5 \mathrm{~g} / \mathrm{kg}$ body weight i.p.) in American obese-hyperglycemic mice (obob) with contribution to age (week) and body weight (g)

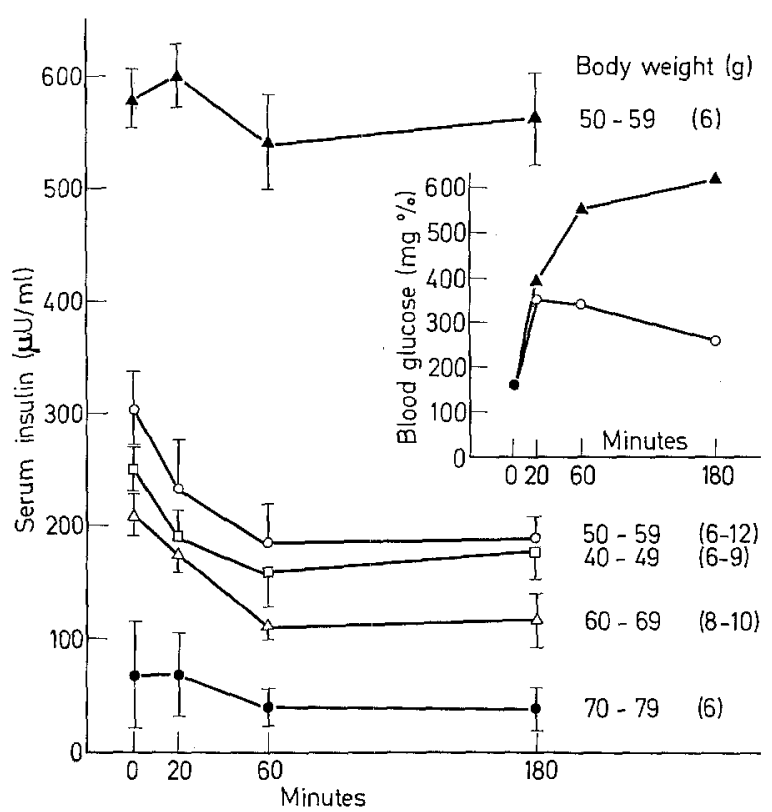

Fig. 7. Immunoreactive serum insulin (mean \pm SEM) during glucose tolerance test $(2.5 \mathrm{~g} / \mathrm{kg}$ body weight i.p.) in American obese-hyperglycemic mice (obob) with contribution to body weight. The number of animals is indicated in parentheses 
The peak of blood sugar values during glucose tolerance tests appears $20 \mathrm{~min}$ after glucose injection. The subsequent slope is similar in most groups, but is delyed in mice older than 7 months $(60-79 \mathrm{~g})$. In contrast to NZO mice $o b o b$ mice of more than $50 \mathrm{~g}$ showed declining blood sugar values before and after glucose load. Therefore, in mice $6-7$ weeks old $(30-39 \mathrm{~g})$ and $5-7$ months $(50-59 \mathrm{~g})$ the reaction to glucose load may be equal in spite of the different age and body weight.

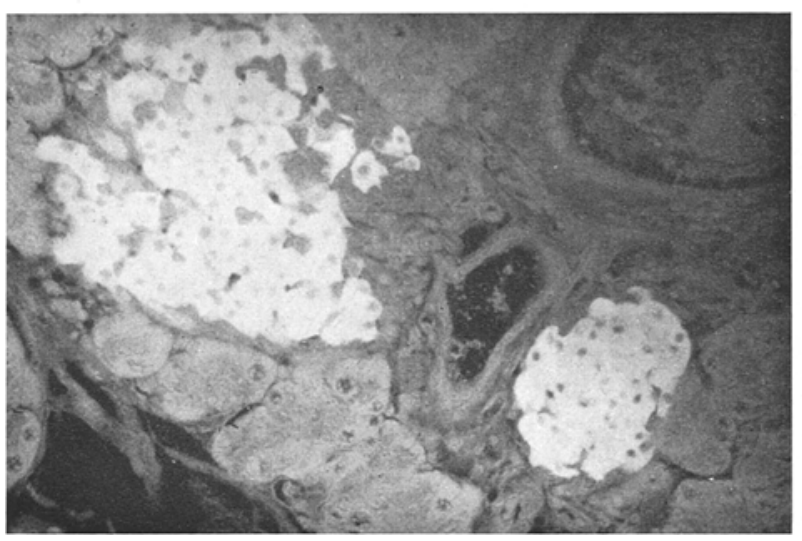

Fig. 8. Lean littermate. Normal sized islets with well granulated B-cells (white). Pseudoisocyanin stain, uv-light, $\times 500$

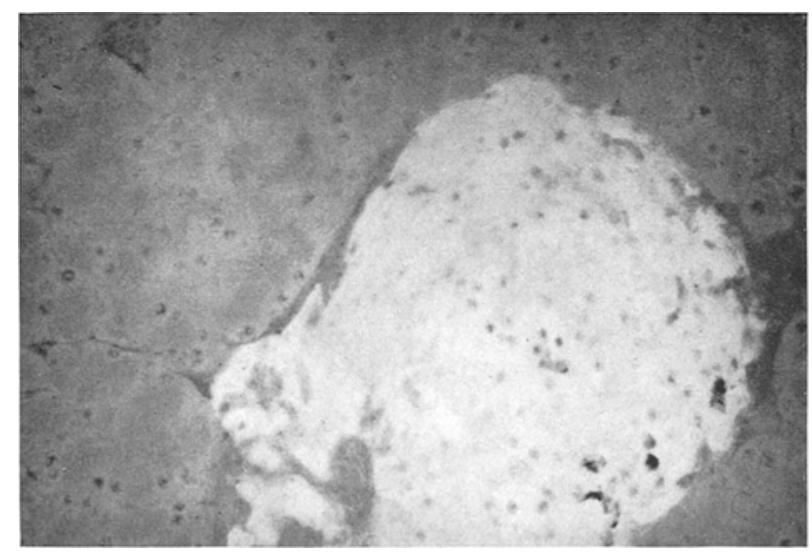

Fig. 9. Obob, 45 g. Moderately enlarged islet, well granulated B-cells. Pseudoisocyanin stain, uv-light, $\times 300$

As shown in Fig. 4 the greatest blood sugar values are seen in 3 months old animals weighing between $40-49 \mathrm{~g}$, the lowest blood sugar values being measured in animals of 8 months, weighing about $65 \mathrm{~g}$. Consequently, it can be stated that, in contrast to NZO mice, glucose tolerance in obob mice is not diminished with increasing body weight. Furthermore, the correlation of blood glucose level to fat cell size observed in NZO mice was seen only in animals of less than $50 \mathrm{~g}$ (Fig. 5). In obob mice weighing 50-59 g, the average blood glucose level declined, whereas the fat cell size increased. Thereafter, the fat cell diameter as well as the average blood glucose declined with increasing body weight. This points to another difference between $o b o b$ and $\mathrm{NZO}$ mice.

Although the great number of tests resulted in a small variance of the glucose values, a remarkable variability of blood sugar levels after glucose load was observed in the group of mice weighing $50-59 \mathrm{~g}$. It could be shown that this variability is a consequence of two different patterns of glucose tolerance tests

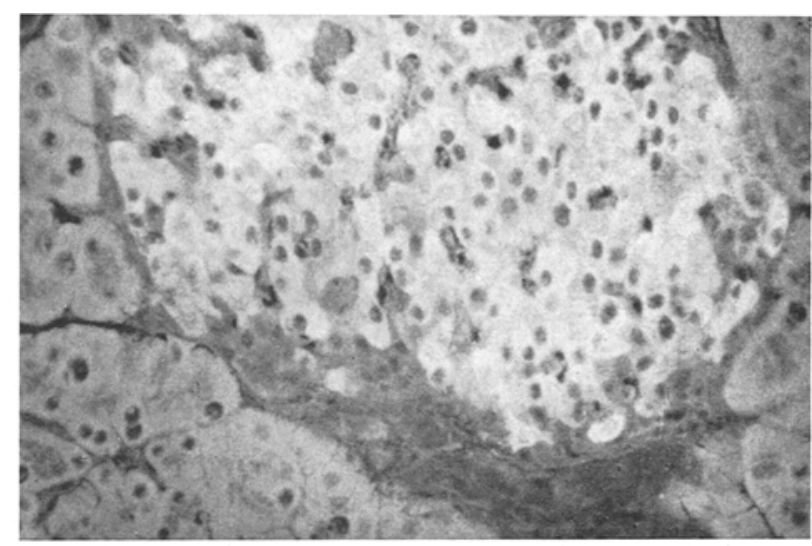

Fig. 10. Obob, 55 g. Moderately enlarged islets with part. ly degranulated B-cells (bright gray). Pseudoisocyanin stain, uv-light, $\times 500$

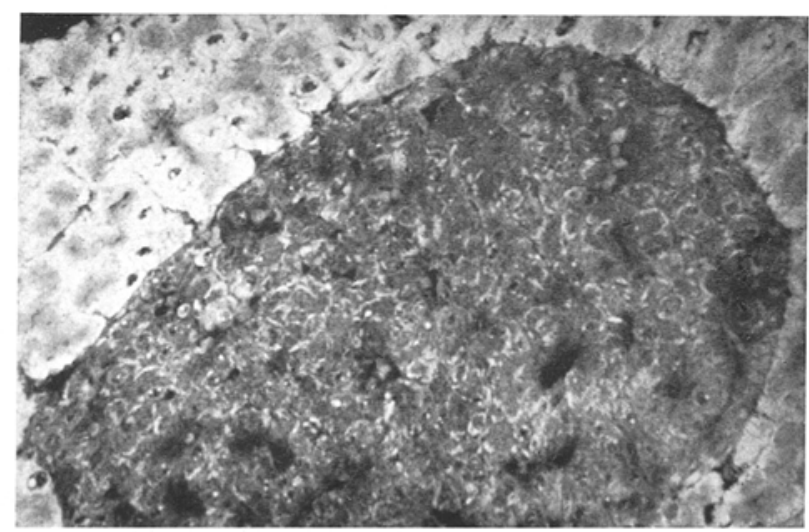

Fig. 11. Obob, 55 g. Enlarged islets with completely degranulated B-cells (dark gray). Cell membrane only fluorescent. Pseudoisocyanin stain, uv-light, $\times \mathbf{3 0 0}$

which we could only distinguish in this weight group; one type is characterised by high blood glucose levels which rise continuously till the end of the test; the other type shows significantly lower levels with a peak at $20 \mathrm{~min}$ post glucose load and resembles the glucose curve in older animals. It could be shown in an additional study with a second group of animals (Fig. 6) that the first glucose tolerance test type precedes the second and that the two types are probably confined to only a short period of time, since the change in pattern occurred during an interval of 3 weeks. These 
different types of glucose tolerance are parallelled by marked differences in serum insulin, as shall be discussed below.

As it is assumed that differences in glucose tolerance test are related to serum insulin levels, we measured serum insulin after glucose load (Fig. 7). In lean littermates the levels of insulin were not significantly different from zero-value at all time. In non-fasted $o b o b$ mice serum insulin, like blood sugar, has a tendency to

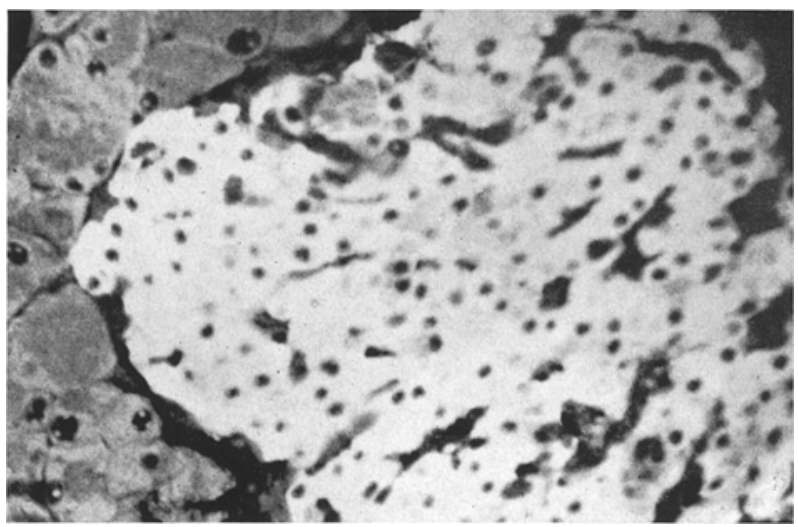

Fig. 12. $O b \circ b, 12$ months of age. Enlarged islet, well granulated B-cells. Pseudoisocyanin stain, uv-light, $\times 500$ $\mathrm{g}$ body weight. It could be shown that this variability was due to the presence of two clearly different groups, which corresponded to the animals with glucose tolerance tests of type one and type two, respectively. As demonstrated in Fig. 7, the animals with extremely

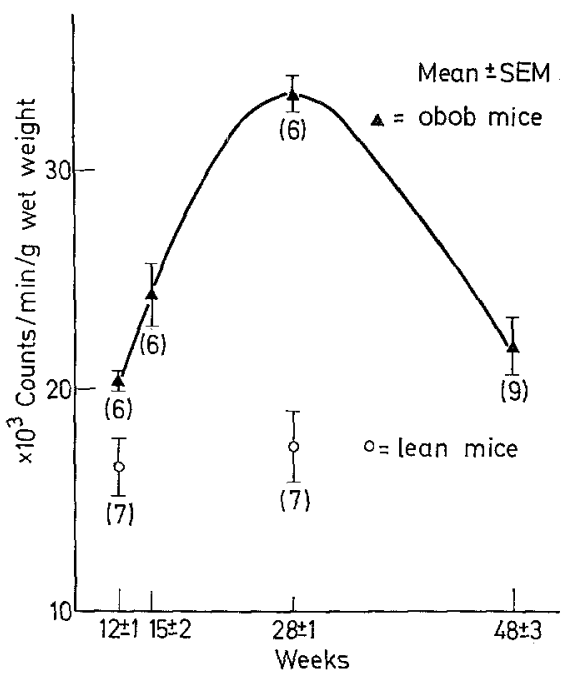

Fig. 13, ${ }^{14} \mathrm{CO}_{2}$-fixation in liver slices of American obesehyperglycemic mice $(o b o b)$. The number of experiments is given in parentheses

Table. Activities of piruvate carboxylase and phosphoenolpyruvate carboxykinase in liver slices of lean and obob mice

\begin{tabular}{|c|c|c|c|c|c|c|}
\hline & \multicolumn{2}{|c|}{ Liver weight Protein } & \multicolumn{2}{|c|}{ Pyruvate carboxylase(a) } & \multicolumn{2}{|c|}{$\begin{array}{l}\text { Phosphoenolpyruvate } \\
\text { carboxykinase (b) }\end{array}$} \\
\hline & g & $\%$ & $\begin{array}{l}\text { punits/g wet } \\
\text { weight }\end{array}$ & $\begin{array}{l}\text { punits/mg } \\
\text { protein }\end{array}$ & 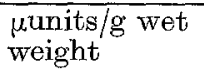 & $\begin{array}{l}\text { punits/mg } \\
\text { protein }\end{array}$ \\
\hline \multirow[t]{5}{*}{1.} & & & & & & \\
\hline & 1.56 & 16.7 & 1.35 & 8.4 & 6.67 & 39 \\
\hline & 1.34 & 16.3 & 1.24 & 7.6 & 5.42 & 33 \\
\hline & 1.02 & 16.0 & 1.49 & 9.3 & 4.82 & 30 \\
\hline & 1.32 & 16.4 & 1.32 & 8.0 & 5.23 & 30 \\
\hline \multicolumn{7}{|l|}{2.} \\
\hline & 3.24 & 16.9 & 1.26 & 7.4 & 5.70 & 34 \\
\hline & 3.69 & 16.5 & 1.28 & 7.7 & 5.92 & 35 \\
\hline & 3.41 & 17.0 & 1.45 & 8.5 & 5.59 & 33 \\
\hline & 3.28 & 16.6 & 1.39 & 8.4 & 5.64 & 35 \\
\hline
\end{tabular}

$1 .=$ lean

2. $=o b o b$

(a) = one unit is defined as the amount of enzyme catalyzing the carboxylation of 1 $\mu$ mole pyruvate $/ \mathrm{min}$ at $30^{\circ} \mathrm{C}$ in the assay described by Henning and Seubert [10].

(b) = one unit is defined as the amount of enzyme catalyzing the formation of 1 umole phosphoenolpyruvate at $30^{\circ} \mathrm{C}$ in the assay described by Seubert and Huth $[20]$.

decline with age. However, the highest values are measured in animals weighing $50-59 \mathrm{~g}$. It is surprising that the insulin levels showed no increase but a decrease after glucose load. It is possible that an early peak within the first $20 \mathrm{~min}$ of glucose load may have been missed. Again, we found not only the highest but the most variable insulin levels in the group of $50-59$ high insulin levels have increasing blood sugar levels up to $180 \mathrm{~min}$ post glucose load. Moderately high insulin levels are seen in animals with relatively low blood sugar levels, which decline after the $20 \mathrm{~min}$ peak.

Histological examinations of the endocrine pancreatic tissue show that in lean littermates with low non-fasting blood sugar values, B-cells are filled with 
fluorescent material indicating a good granulation (Fig. 8). In obob mice weighing about $45 \mathrm{~g}$ and showing non-fasting blood sugar values of about $250 \mathrm{mg} \%$ (Fig. 9) the size of the islets is enlarged see also $[2,6,9,27]$. The B-cells are well granulated, which is illustrated by the fluorescent spaces within the cells. In mice weighing approx. $55 \mathrm{~g}$, two typical examples will be shown (Fig. 10). In one animal, the granulation is similar to that seen in the group of mice weighing $40-49 \mathrm{~g}$ (Fig. 11), yet in another animal only a small rim of fluorescent material is visible near the cell membrane. No blood sugar or serum insulin determinations were performed on the day the animals were killed, and we can only presume that the two different stages of granulation parallel the different levels of blood glucose and serum insulin. In mice of more than 10 months of age with increased glucose tolerance (Fig. 12), well granulated B-cells as well as degranulated B-cells can be seen.

Gluconeogenic capacity in liver slices. Insulin has been reported to be a suppressor of corticoid-induced increase in gluconeogenic enzyme activities [24]. Therefore, one may assume that the high blood sugar levels in $o b o b$ mice are due to a defective muscular insulin responsiveness [22] rather than to elevated levels in gluconeogenic enzymes as a result of increased production of corticosterone $[3,8]$.

We therefore studied the gluconeogenic capacity of liver slices by means of $\mathrm{CO}_{2}$-fixation. As shown in Fig. 13, $\mathrm{CO}_{2}$-fixation is significantly increased in $o b o b$ mice. In young $o b o b$ mice, exhibiting the highest insulin levels, $\mathrm{CO}_{2}$-fixation is smaller than in mice with with relatively lower insulin levels. This would confirm the hyphothesis mentioned above. However, the markedly decreased $\mathrm{CO}_{2}$-fixation in old mice with the lowest insulin levels is very striking. Our results are in good agreement with those reported by other authors $[4,19$, 26] who observed increased gluconeogenic enzyme activities in hyperglycemic mice. When measuring the activities of pyruvate carboxylase and phosphoenolpyruvate carboxykinase, the two enzymes which are involved in the abbreviated dicarboxylic acid shuttle, we did not see any difference between lean littermates and $o b o b$ mice as shown in Table 1 . These results are in contrast with those expected from our $\mathrm{CO}_{2}$-fixation studies. The discrepancy may be due to a different intracellular distribution of pyruvate carboxylase [11] or to different levels of acetyl-CoA $[13,23]$ and needs further investigation.

\section{References}

1. Bielschowsky, M., Bielschowsky, F.: The New Zealand strain of obese mice. Their response to stilboestrol and to insulin. Aust. J. exp. Biol. med. Sci. 34, $181-198(1956)$.

2. Bleisch, V.R., Mayer, J., Dickie, M.M.: Familial diabetes mellitus in mice, associated with insulin resistance, obesity, and hyperplasia of the islands of Langerhans. Amer. J. Path. 28, 369-381 (1952).
3. Carstensen, H., Hellman, B., Larsson, S.: Biosynthesis of steroids in the adrenals of normal and obese-hyper. glycemic mice. Acta Soc. Med. upsalien. Läkare för Förhandlinger 66, 139-151 (1961).

4. Coleman, D.L., Hummel, K.P.: Studies with the mutation, diabetes in the mouse. Diabetologia 3, $238-248$ (1967).

5. Crofford, O.B., Davis, Ch.K., Jr.: Growth characteristies, glucose tolerance and insulin sensitivity of New Zealand obese mice. Metabolism 14, 271-280 (1965).

6. Gepts, W., Christophe, J., Mayer, J.: Pancreatic islets in mice with the obese-hyperglycemic syndrome. Diabetes 9, 63-69 (1960).

7. Hales, C.N., Randle, P.J.: Immunoassay of insulin with insulin-antibody precipitate. Biochem. J. 88, $137-146(1963)$.

8. Hellerström, C., Hellman, B., Larsson, S.: Some aspects of the structure and histochemistry of the adrenals in obese-hyperglycemic mice. Acta path. microbiol. scand. 54, 365-372 (1962).

9. Hellman, B., Brolin, S., Hellerström, C., Hellman, K.: The distribution pattern of the pancreatic islet volume in normal and hyperglycemic mice. Acta endocr. 36, $609-616$ (1961).

10. Henning, H.V., Seubert, W.: Zum Mechanismus der Gluconeogenese und ihrer Steuerung. I. Quantitative Bestimmung der Pyruvatearboxylase in Rohextrakten der Rattenleber. Biochem. Z.340, 160-170 (1964).

11. - Stumpf, B., Ohly, B., Seubert, W.: On the mechanism of gluconeogenesis and its regulation. III. The gluconeogenic capacity and the activities of pyruvate carboxylase and PEP-carboxylase of rat kidney and rat liver after cortisol treatment and starvation. Biochem. Z. 344, 274-288 (1966).

12. Hoffman, W.S.: A rapid photoelectric method for the determination of glucose in blood and urine. J. biol. Chem. 120, 51-55 (1967).

13. Keech, D.B., Utter, M.F.: Pyruvate Carboxylase. J. biol. Chem. 238, 2609-2614 (1963).

14. L'Age, M., Henning, H.V., Ohly, B., Seubert, W.: On the role of insulin in the control of gluconeogenesis. Biochem. biophys. Res. Comm. 31, 241-246 (1968).

15. Lowry, O.H., Rosebrough, N.J., Farr, A.L., Randle, P.J.: Protein measurement with the folin phenol reagent. J. biol. Chem. 193, 265 (1951).

16. Malaisse, W.J., Malaisse-Lagae, F., Coleman, D.C.: Insulin secretion in experimental obesity. Metabolism 17, $802-807$ (1968).

17. Salans, L.B., Knittle, J.L., Hirsch, H.: The role of adipose cell size and adipose tissue insulin sensitivity in the carbohydrate intolerance of human obesity. $J$. clin. Invest. 47, 153-165 (1968).

18. Schiebler, T., Schiessler, S.: Über den Nachweis von Insulin mit den metachromatisch reagierenden Pseudoisocyaninen. Histochemie 1, 445-465 (1959).

19. Seidman, I., Horland, A.A., Teebor, G. W.: Hepatic glycolytic and gluconeogenic enzymes of the obesehyperglycemic mouse. Biochim. biophys. Acta 146, $600-603$ (1967).

20. Seubert, W., Huth, W.: On the mechanism of gluconeogenesis and its regulation. II. The mechanism of gluconeogenesis from pyruvate and fumarate Biochem. Z. 343, 176-191 (1965).

21. Sneyd, J.G.T.: Pancreatic and serum insulin in the Now Zealand strain of obese mice. J. Endocr. 28, $163-172(1964)$.

22. Stauffacher, W., Crofford, O.B., Jeanrenaud, B., Renold, A.E.: Comparative studies on muscle and adipose tissue metabolism in lean and obese mice. Ann. N.Y. Acad. Sei. 131, 528 - 540 (1965). 
23. Utter, M.F., Keech, D.B.: Pyruvate Carboxylase. I. Nature of the reaction. J. biol. Chem. 238, 2603-2608 (1963).

24. Weber, G., Singhal, R.L., Stamm, N.B., Fisher, E.A., Mentendiek, M.A.: Regulation of enzymes involved in gluconeogenesis. Enzyme Reg. 2, 1-38 (1963).

25. Westman, S.: Development of the obese-hyperglycemic syndrome in mice. Diabetologia 4, 141-149 (1968).

26. Willms, B., Janson, A., Bernhard, G., Söling, H.D. Enzymatic activity of both hepatic glycoloysis and gluconeogenesis in genetical diabetes in humans and in different laboratory animals. 5. Annual Meeting of the European Association for the study of diabetes. Montpellier, France, 16. 9.-18. 9. 1969.

27. Wrenshall, G.A., Andrus, S. B., Mayer, J.: High levels of pancreatic insulin coexistent with hyperplasia and degranulation of beta cells in mice with the obesehyperglycemic syndrome. Endocrinology 56, 335-340 (1955).

Dr. Dr. L. Herberg

Diabetes-Forschungsinstitut und

2. Medizinische Klinik der

Universität Düsseldorf

D-4000 Düsseldorf, Moorenstr. 5 